\title{
The Concept of Continuous Wellbeing of Older Adults in Contemporary Demographic Shift
}

\author{
Kashchuk Irina ${ }^{\mathrm{a} *}$, Timofeeva Yana ${ }^{\mathrm{b}}$ \\ *Corresponding author: Kashchuk Irina, Irusiya_Kashuk@mail.ru \\ ${ }^{a}$ National Research Tomsk Polytechnic University, Lenin avenue, 30, 634050, Tomsk, Russia, E-mail: Irusiya_Kashuk@mail.ru, \\ telephone number: 9039550943 \\ ${ }^{b}$ National Research Tomsk Polytechnic University, Lenin avenue, 30, 634050,Tomsk, Russia, E-mail: Yana1524@yandex.ru
}

\begin{abstract}
http://dx.doi.org/10.15405/epsbs.2017.01.38

The article is devoted to enhancing the wellbeing of older adults in Russia and abroad. The current trend of rapid growth in the number of the elderly worldwide is considered. The social and economic impacts of modern demographic shift changes are analysed: the structures of market demand, savings patterns, labour supply, budgeted resource requirements, flow of financial resources and obligations. It is proposed to revise the existing economic model of modern society based on a new concept of continuous wellbeing of older adults. A new platform of wellbeing of older adults through their active involvement in the economic life of society is suggested. The option of creating a new concept of wellbeing on the basis of the revival of mentoring is considered. In the framework of a study examines the changes in the market of consumer goods and services; labour market; a system of accumulation and savings; transformation of financial resources.
\end{abstract}

(C) 2017 Published by Future Academy www.FutureAcademy.org.uk

Keywords: Demographic shift, older adults, well-being concept, quality of living, social-economic programme, labour market.

\section{Introduction}

Today the oldest in the world is the population of Europe. The trend of an aging population will soon cover all continents. In developing countries the aging process will be more rapid than in the developed countries of Europe. By 2050 80\% of elderly people will be living in developing countries. What is the reason? Do people have fewer children or live longer? Today people on all continents of the earth live longer. Life expectancy is increasing every year. Annually Life Expectancy Index 
publishes the index of life expectancy, which is a key indicator of life expectancy in the world. 2014 data are presented in table 1 (Ranking of countries in terms of life expectancy, 2016).

Table 1. Life Expectance Index.

\begin{tabular}{ccc}
\hline Rank & Country & Life expectancy (age) \\
\hline 1 & Japan & 83.6 \\
2 & Hong Kong & 83.4 \\
3 & Switzerland & 82.6 \\
4 & Australia & 82.5 \\
5 & Italy & 82.4 \\
6 & Singapore & 82.3 \\
7 & Iceland & 82.1 \\
8 & Spain & 82.1 \\
9 & Sweden & 81.8 \\
10 & Israel & 81.8 \\
12 & Russia & 68 \\
\hline
\end{tabular}

\section{The consequences of the demographic shift}

Demographic changes entail the following social and economic consequences.

1. Changes in the structure of demand for market goods and services, including the services provided by the state. With increasing age the demand for health services increases. Older adults are more at risk of disease and require more medical care. Increasing proportion of the elderly in the population will lead to higher health care costs for the state, and decline in fertility will lead to reduction in kindergartens and schools attendance.

2. The needs of older adults have their own specifics, so their demands for goods and services differ from those of other age groups. As a rule, these requirements are not taken into account in the production in many sectors of economy activity. The modern concept of gerontomarketing can solve all the problems associated with the production, acquisition and use of goods and services by older adults. Gerontomarketing is aimed at finding and developing the market of the elderly as a target for manufacturers and distributors, and to ensure the demand for goods and services to customers over the age of 55. Gerontomarketing makes it possible to adjust the basic parameters of quality and standard of living of an older adult.

3. Changing the volume and structure of savings. Periods of formation and usage of savings alternate. Shifts in the age structure of the population significantly affect their dynamics. Reducing the proportion of people of young and middle age decreases the load on the working 
population, and the elderly population growth creates an additional load on public finances, increasing the need for transfers from the budget. As a result, the demand for financial assets and interest rates changes. In developed countries, Germany, France, Finland, Switzerland, retirees are financially secure. Their pension is greater than that of the Russians, both in absolute and in relative terms. In western countries pensions are comparable with the salary of an average worker and run up to 60-70 per cent of its average size. Therefore, the tendency of increase of savings due to savings of pensioners abroad is much higher than in Russia. In our country, due to low salaries and pensions, there are virtually no savings.

4. Reduced demand in the labour market. In Russia, the demographic changes will lead to reduction in the number of economically active population of 20 million people; it significantly slows the growth of per capita GDP at constant level of labor productivity. Accordingly, all other things being equal, aging slows down the growth of living standards of the population.

5. A significant increase in the need for budgetary resources. The government spends a huge amount of funds for the development of programs to improve the lives of elderly people. However, none of them solve all the complex problems of the elderly. Regions, developing their programs, are guided only by the generalised statistical data about one or another sphere of life and do not take into account the perception of and satisfaction with the quality of life of the population of specific age groups.

6. A significant change in flow of financial resources and obligations between generations. "Easy" way to solve budget problems associated with the demographic shift is to increase the national debt. There is a disturbance of the balance between the generations as a result of changes in the working population and retirees who still work. According to Rosstat, in Russia at the moment 40 million people receive retirement pensions and one of in three continues to work, that is, a working pensioner.

Over the past 20 years, the problem of aging has become the most urgent worldwide.

Today every ninth person in the world is 60 years old or more. By 2050 every fifth person in the world will be more than 60 years old, according to the forecasts of Department of Economic and Social Affairs (World Population Ageing, 2015). The data is presented in Table 2 and 3.

Table 2. Number of people aged 60-80.

\begin{tabular}{ll}
\hline Year & Billion \\
\hline 2015 & 0,901 \\
2030 & 1.4 \\
2050 & 2,1 \\
\hline
\end{tabular}

Table 3. Life expectancy.

\begin{tabular}{ll}
\hline Year & Age \\
\hline 2015 & 70,5 \\
2030 & 73,6 \\
2050 & 77,1 \\
\hline
\end{tabular}


What are the economic consequences of these trends? What awaits us in the future? According to UN projections, by 2050 in all regions of the world, except Africa, there will be about 2 billion people aged over 6 ( $22 \%$ of the world population). Their number exceeds the number of children under 15 , and the population of working age will increase only by 1.1 billion people. The data are presented in Table 4. By 2050 the developing countries the labor force will grow rapidly and will exceed the number of current workforce in developed countries.

Table 4. There will be older adults than children under 15 by 2050.

\begin{tabular}{llll}
\hline Year & Persons aged 60+ & Children under 15 & Children under 5 \\
\hline 2015 & 901 million & 1.7 billion & 500 million \\
2030 & 1.4 billion & 1.8 billion & 600 million \\
2050 & 2.1 billion & 2 billion & 600 million \\
\hline
\end{tabular}

According to the forecasts of the statistical service of the European Union in 2050 in developed countries 100 employees will account for 78 unemployed. Most of them will be retired. For example, in Japan in 2050100 workers will account for 99 pensioners.

It is clear that soon the current economic model, which provides workable all pensioners will be unreal. Discussions mainly deal with potential models of pension systems and health insurance systems. It is necessary to develop a new economic model and a new concept of wellbeing of older adults (The balance between Generations in an Ageing Europe, 2016).

\section{Changing the aging of the world population}

Development and implementation of a new economic model may be subject to changes in the population aging process in the world. An instant change of population aging process is not possible. This is a complex tedious work at improving the quality of life and wellbeing of older adults.

The image of an elderly man from a prosperous country is a financially secure, leading an active lifestyle, traveling a lot, a curious citizen who is inclined to wonder and change. People who enjoy their lives do not have to run to work every day early in the morning, their children are adults, they have savings.

In Russia today there is the situation when enterprises, on the one hand, try to force a person to retire, and, on the other hand, take them in tow paying taxes for their perpetual vacation for decades.

Until recently it was believed that pension is financial payment, which the elderly can count on. By the end of the twentieth century, western studies have shown that a large number of older people remain physically fit after 60 .

If in 20 years half of the world's population is older adults, who will support them and feed them? This situation will lead to the collapse of the pension system in all countries of the world. The Government of Russia and some European countries propose to increase the retirement age.

The question arises: how economically useless are the elderly? Are they unable to work?

The economist Robert Samuelson in "Aging America", wrote, "We need to discard the prejudice that after 65 a person must be taken under states' wing. People do not become poor and miserable the next day after their 65th birthday. I never liked the expression "greedy geezers". It is offensive and puts 
stamp on the generation of people born during the Depression and World War II, only for the fact that they were lucky to survive and live a long time. But there is a limit. If politicians belonging to the generation of demographic explosion do not change the situation, we can be sure that our children will call us greedy geezers. They will be right " (Knowledge is power popular science magazine. The third age, 2013).

Today millions of elderly people have to stay out of work. Among them, there are a lot of those who are willing and able to work, but the labour market does not give them such an opportunity.

There is the problem of attracting older adults to productive work because of the public opinion that their work is not effective.

In real life there are many situations when the competitors in the labour market are elderly efficient specialists and young inexperienced workers without professional knowledge (e.g. migrants). Who is more attractive for the labour market? From an economic point of view, elderly specialists are preferable. They do not need to train, adapt, and are unlikely to take every opportunity to find a new employer and bigger salary.

Research by Marksman, which selects personnel for companies of various levels and directions, from small businesses to international corporations, showed that the most dedicated and enthusiastic staff in the companies is over 50 years old. Since these people are more customer-centric (MARKSMAN in Mass Media, 2016).

The world's leading consulting companies consider the potential use of older people's labour real and economically justified.

Western governments are making great efforts towards the wellbeing of older adults. But the problem of employment discrimination of the elderly is not completely solved.

Every year the number of potential new workers in the labor market is reduced. Modern enterprises are in a situation when old highly skilled workers have already retired, and there is shortage of qualified skilled workers at the working age in the labuor market. It is necessary to compete for them and pay more.

"Leakage of knowledge" as a result of generation dismissal, keeping up with technological progress, is not unique to Russia. In this situation the solution to the problem could be the revival of mentoring worldwide. Bosch gives all retired the opportunity to interview in which they can express their ideas, suggestions and share experiences. In Swedish construction company Elmhults Konstruktions and Danish company Hazenberg Bouw there is mentoring system that motivates retiring workers to transfer knowledge to the young. In Russian Corporation "Mechel" a special council of veterans is organised and mentoring system is established (Aging, 2013).

Today the state must stimulate all companies to hire older adults. Incentives may be different, such as tax advantages. It is necessary to take into account the specifics of the proposed employment programs for older people. Specificity may consist in reducing the intensity of work, flexible working hours, part-time work and other exemptions, taking into account the peculiarities of gerontology of the elderly.

The main motivation of the elderly is attentive and respectful attitude to them, to their seniority and qualifications. For many retirees job loss means loss of self, loss of reference points and goals in life. 
Any form of pensioners' participation in some creative activities for a modest fee will provide a positive impact both on businesses and society as a whole.

Russia lags far behind western countries in terms of attracting older people to productive activities.

\section{The concept of wellbeing of older adults on the basis of the revival of the mentoring institute}

To create and implement the concept of wellbeing of older adults by involving them in the economic life attention should be paid to health, education and the sphere of consumption.

People, who have health problems, are unlikely to work in retirement age. Everybody should take care of health from youth. The state should help by improving medical service, upbringing and education.

Health care is not just medicine. It is a healthy lifestyle, proper nutrition, exercise. The Sectors of economy that provide prevention and treatment of diseases are extremely important in an aging society.

Why is education necessary? Why should an elderly person study? It is not about to give new skills, new information and scientific breakthroughs. Education is necessary for the development of new jobs in new environment: new goals, objectives, technologies, techniques and other work tools.

In the society where a significant portion of the citizens are pensioners consumption patterns are changing. More and more companies today are guided by the consumption of the elderly. For example, Whirlpool designs equipment considering testing with potential customers who suffer from deafness, lack of vision or arthritis. Whirlpool developed, for example, a stand for washing machines for the elderly not to bend. Cell phone manufacturers already have models that, unlike the newfangled gadgets, are simplified, information is displayed on the LCD in bright and large print.

Older adults actively create demand in western countries. They are considered a target audience for many consumer markets.

With the development of the demographic trend of an aging society the relevance of gerontomarketing will increase.

The average life expectancy in Russia is 66 years. This figure says that today it is important to prevent the pace and timing of elderly population mortality. Our pensioners after retirement do not go on a journey, but begin to treat a bouquet of chronic diseases. The main motivation for them to work is low income.

Some industries are actively using pensioners' labour. They are industrial workers and engineers in research and production associations. In these industries, the average age of skilled workers and engineers is 60 (In the search for a new "Silver Age" in Russia, 2016).

In today's competitive world young people are mostly pursuing their personal interests, unlike the elderly, who were "Soviet cadres" and reflected the communist ideology.

The aging population may serve as an effective economic resource in modern society and benefit the country and the world as a whole. By creating and implementing a new concept of wellbeing of older adults it is possible to build a kind of social-economic platform of modern developing society, where the state creates all conditions for the continuous wellbeing of older adults, and they, in turn, contribute to the economic prosperity of the country. 


\section{Conclusion}

In today's world there is a demographic shift as a result of the rapid increase in the proportion of the elderly in the total population of the world.

Demographic changes will entail the corresponding social and economic impact. There will be changes: in the market of consumer goods and services; in the job market; in the system of accumulation and savings; in transformation of financial resources. The need for budgetary resources will increase.

These effects cause the urgent need to revise the existing economic model of society. Modernization of the system of pensions and health insurance, education and employment will be of particular importance.

It is proposed to create a new concept of wellbeing of older adults on the basis of universal, economically feasible way to bring them to productive and motivated work. It necessitates special conditions of work for older adults and revival of mentoring.

\section{Acknowledgements}

This work was performed by the authors in collaboration with Tomsk Polytechnic University within the project in Evaluation and enhancement of social, economic and emotional wellbeing of older adults under the Agreement No.14.Z50.31.0029.

\section{References}

Aging (2013). Retrieved from http://expert.ru/russian_reporter/2013/03/stareem/media/178037/

In the search for a new "Silver Age" in Russia (2016). Retrieved from

http://www.worldbank.org/en/country/russia/publication/searching-for-a-new-silver-age-in-russia-the-driversand-impacts-of-population-aging

Knowledge is power popular science magazine (2013). Retrieved from http://www.znaniesila.su/?issue $=$ articles/issue_3358.html\&rr=3\&razd=1\&r=1 (the date of access: $05 / 02 / 2016$ ). (in Russian)

MARKSMAN in Mass Media (2016). Retrieved from http://www.marksmans.ru/press-center/our-articles/almosthalf-of-the-companies-in-the-russian-federation-is-experiencing-a-shortage-of-skilled-personn/ (in Russian)

Ranking of countries in terms of life expectancy (2016). Retrieved from http://gtmarket.ru/ratings/life-expectancyindex/life-expectancy-index-info (in Russian)

The balance between Generations in an Ageing Europe (2016). Retrieved from http://ec.europa.eu/eurostat/documents/3217494/5740649/KS-EP-11-001-EN.PDF/1 f0b25f8-3c86-4f40-9376c737b54c5fcf

World Population (2015). Retrieved from http://un.org/en/development/desa/population/theme/ageing/WPA2015.shtml 